\title{
Orchard Floor and Nitrogen Management Influences Soil and Water Quality and Tart Cherry Yields
}

\author{
Jose E. Sanchez ${ }^{1}$ \\ Oklahoma Panhandle Research and Extension Center, Oklahoma State University, Goodwell, OK 73939 \\ Charles E. Edson, George W. Bird, and Mark E. Whalon \\ Center for Integrated Plant Systems, Michigan State University, East Lansing, MI 48824
}

Thomas C. Willson

Southwest Kansas Research and Extension Center, Kansas State University, Garden City, KS 67846

Richard R. Harwood

Department of Crop and Soil Sciences, Michigan State University, East Lansing, MI 48824

Kadir Kizilkaya

Department of Animal Science, Adnan Menderes University, Aydin, 09100 Turkey

James E. Nugent, William Klein, and Alan Middleton

Northwest Michigan Horticultural Research Station, Traverse City, MI 49684

Theodore L. Loudon

Department of Agriculture Engineering, Michigan State University, East Lansing, MI 48824

Dale R. Mutch

Kellogg Biological Station, Michigan State University, Hickory Corners, MI 49060

Joseph Scrimger
Bio-Systems, Marlette, MI 48453

Additional Index words. Prunus cerasus, mulch, compost, cover crop, organic matter, nematode community structure, nitrate leaching

\begin{abstract}
Designing and implementing more productive, nutrient-efficient, and environmentally sound orchard management systems requires a better understanding of plant and soil responses to more biologically driven management practices. This study explored the effect of orchard floor and $\mathrm{N}$ management on soil organic $\mathrm{C}$ and $\mathrm{N}$, populations of nematodes, $\mathrm{NO}_{3}$ leaching, and yields in tart cherry (Prunus cerasus L. 'Montmorency') production. A baseline conventional orchard system consisting of an herbicide-treated tree row and a full rate of $\mathrm{N}$ fertilizer was compared to two modified-conventional and ten alternative orchard floor and $\mathrm{N}$ management systems. Living ground cover and the use of mulch with or without composted manure increased total $\mathrm{C}$ and the active $\mathrm{C}$ and $\mathrm{N}$ pools in the soil. For instance, supplemental mulch or mulch applied using a side-delivery mower increased soil $\mathrm{C}$ by $>20 \%$ above the conventional baseline. The size of the active $C$ pool increased $45 \%$ and $60 \%$ with the use of the species mix 2 ground cover and compost, respectively. Increases in the active $\mathrm{N}$ pool ranged from a low of $25 \%$ in the soils using mulch or a ground cover mix to a high of $60 \%$ when compost was used. As a result, the ability of these soils to provide $\mathrm{N}$ to growing plants was enhanced. Total soil $\mathrm{N}$ increased in the treatment using natural weeds as ground cover and the full rate of $\mathrm{N}$ fertilizer. It is likely that weeds were able to convert significant amounts of fertilizer $\mathrm{N}$ into organic forms. Increasing the active $\mathrm{C}$ and $\mathrm{N}$ pools stimulates microbial activity, and may favor populations of nonplant parasitic nematodes over plant parasitic species. Using a trunk-to-trunk cover crop mix under the cherry trees reduced $\mathrm{NO}_{3}$ leaching by $>90 \%$ compared to a conventional, herbicide treated soil, even when $\mathbf{N}$ fertilizer was used at full rate. Nitrate leaching also dramatically diminished when $\mathbf{N}$ fertilizer was fertigated at a reduced rate or when compost was used as $\mathbf{N}$ source. Alternative orchard floor and $\mathbf{N}$ management did not reduce yields when compared to the baseline conventional treatment.
\end{abstract}

Reducing weed competition for nutrients and water is a major objective in fruit production. The goal is to provide a vegetative free zone in the tree rows to minimize competition to tree growth while maintaining soil structure in the alley (Parker and Hull, 1993). Herbicide-treated tree rows with grass alleys are standard orchard floor management practices in the United States (Shribbs

Received for publication 17 May 2002. Accepted for publication 2 Dec. 2002. This research was funded in part by the Michigan Department of Agriculture, United States Department of Agriculture, and Michigan Agricultural Experiment Station. We thank Cherry Bay Orchard for providing the orchard and cooperating with researchers throughout the study.

${ }^{1}$ Corresponding author; e-mail sanchje@okstate.edu. and Skroch, 1986). However, the prolonged use of preemergence herbicide depletes soil organic matter in the unprotected tree row (Merwin, 1998). This most likely occurs because the soil is susceptible to erosion losses and because its capacity to replenish soil organic matter is limited by the reduced amount of plant biomass returned to the soil. The soil's ability to provide nutrients, especially N, to growing plants and to hold water is diminished due to the declining level of soil organic matter (Mc Kenney et al., 1993).

Mulches and cover crops within the tree rows are alternatives to conventional herbicide or cultivation for weed management. In addition, a mulch layer protects the soil from desiccation and 
excessive heating, and optimizes the conditions for the decomposition and mineralization of organic matter. It also protects the soil from erosion caused by heavy rain and wind (Kotschi et al., 1990). A potential downside is that the area immediately surrounding the trunk should be kept mulch-free to avoid disease, insect, or rodent problems.

The potential benefits of using cover crops are less clear, and may vary depending on a number of factors. Turfgrasses are probably the most manageable groundcover for fruit production, but grass species can effectively compete with trees for soil $\mathrm{N}$ and moisture (Goode and Hyrycz, 1976). In contrast, legume cover crops, such as white clover (Trifolium repens L.), appear to have no adverse effect on yield, fruit size, or tree vigor when compared with conventionally treated plots receiving the same amount of fertilizer (Smith et al., 1961). One of the most remarkable benefits of using legumes as a groundcover is their ability to live in a mutually beneficial relationship with $\mathrm{N}$-fixing bacteria. Legumes take up significant amounts of fixed $\mathrm{N}$, resulting in an increase of the active N pool when their residues enter the soil (Sanchez et al., 2001). A more sizeable active $\mathrm{N}$ pool is likely to enhance $\mathrm{N}$ available to plants as a result of increased mineralization (Hesterman et al., 1986). Annual application of composted manure is an additional tool that can be used to enhance the active $\mathrm{N}$ pool. Its contribution will depend on the quantity, quality, and degree of humification of the composted material (Castellanos and Pratt, 1981).

Conventionally managed orchards rely heavily on $\mathrm{N}$ fertilizer applications because the soil has limited $\mathrm{N}$ mineralization capacity (Hanson and Proebsting, 1996). Using high rates of fertilizers can achieve high yields but may affect water quality (Keeney, 1989). This situation can be exacerbated when fruit is produced on coarse textured soils, due to the limited retention capacity of these soils, causing leaching of nutrients and certain pesticides below the root zone. Since most of the drinking water in Michigan filters through the soil before entering an aquifer, elevated levels of $\mathrm{NO}_{3}$ in groundwater are a concern for communities in fruit production areas. The potential negative environmental impact of the input-based soil system, increasing cost of energy, and risk generated by dependency on off-farm inputs, are incentives for looking at alternatives for successful fruit production. The selection of appropriate orchard floor and $\mathrm{N}$ management strategies may represent an effective way to enhance soil quality and reduce $\mathrm{NO}_{3}$ leaching losses.

In this study, a baseline conventional orchard management system was compared to two modified conventional and ten alternative systems. The primary objective was to determine the impact of orchard floor and $\mathrm{N}$ management on soil $\mathrm{C}$ and $\mathrm{N}$, nematode populations, $\mathrm{NO}_{3}$ leaching, and yields in tart cherry (Prunus cerasus L.) production. Total $\mathrm{C}$ and $\mathrm{N}$ and their active mineralizable forms were used as indicators of soil organic matter status and food availability for soil organisms, respectively. Enhancing the active $\mathrm{C}$ and $\mathrm{N}$ pools, the portion of soil $\mathrm{C}$ and $\mathrm{N}$ susceptible to mineralization in the short-term (Paul and Clark, 1996), are likely to increase soil microbial activity and the soil's

Table 1. Summary of treatment differences.

\begin{tabular}{|c|c|c|c|c|}
\hline Treatment & $\begin{array}{l}\text { Orchard floor } \\
\text { management }\end{array}$ & $\begin{array}{l}\mathrm{N} \text { fertilizer } \\
\text { method }\end{array}$ & $\begin{array}{l}\mathrm{N} \text { fertilizer } \\
\text { rate }\end{array}$ & $\begin{array}{l}\text { Supplemental } \\
\text { irrigation }^{\mathrm{z}}\end{array}$ \\
\hline \multicolumn{5}{|l|}{ Conventional $^{y}$} \\
\hline Spring simazine $+\mathrm{N}$ & $\begin{array}{l}\text { Spring simazine } 3.2 \mathrm{~kg} \cdot \mathrm{ha}^{-1} \text { a.i., } \\
\text { Glyphosate } 1.6 \mathrm{~kg} \cdot \mathrm{ha}^{-1} \text { a.i. if needed }\end{array}$ & Broadcast & Standard $^{\mathrm{x}}$ & No \\
\hline Spring simazine + fertigation $\mathrm{N}$ & Spring simazine, glyphosate if needed & Fertigation & Reduced $^{\mathrm{w}}$ & Yes (with N) \\
\hline Fall simazine $+\mathrm{N}$ & Fall simazine, glyphosate if needed & Broadcast & Standard & No \\
\hline \multicolumn{5}{|l|}{ Mulch } \\
\hline Side delivery & $\begin{array}{l}\text { Side delivery mulch (from alleyway), } \\
\text { Glyphosate if needed }\end{array}$ & Broadcast & Standard & No \\
\hline Side delivery + fertigation $\mathrm{N}$ & $\begin{array}{l}\text { Side delivery mulch (from alleyway), } \\
\text { Glyphosate if needed }\end{array}$ & Fertigation & Reduced & Yes (with N) \\
\hline Supplemental & Supplemental mulch & Broadcast & Standard & No \\
\hline \multicolumn{5}{|l|}{ Vegetative cover } \\
\hline Species mix $1^{\mathrm{v}}$ & Groundcover species mix 1 & Broadcast & Standard & Yes \\
\hline Species mix $2^{u}$ & Groundcover species mix 2 & Broadcast & Standard & Yes \\
\hline Species mix $2+$ fertigation $\mathrm{N}$ & Groundcover species mix 2 & Fertigation & Reduced & Yes (with N) \\
\hline Species mix $3^{t}$ & Groundcover species mix 1 & Broadcast & Standard & Yes \\
\hline Natural species mix & None & Broadcast & Standard & Yes \\
\hline \multicolumn{5}{|l|}{ Compost } \\
\hline Regular & Side delivery mulch (from alleyway) & None & None & No \\
\hline Biosystem & Side delivery much (from alleyway) & Broadcast & Alternative $^{\mathrm{s}}$ & Yes \\
\hline
\end{tabular}

The same amount of water was applied to treatments receiving supplemental irrigation.

yConventional systems used a 3-m-wide herbicide strip.

${ }^{\mathrm{x}}$ Ammonium nitrate was applied at the following rates $\left(\mathrm{kg} \cdot \mathrm{ha}^{-1} \mathrm{~N}\right): 55$ in 1995, 150 in 1996, 110 in 1998, and 120 in 1997, 1999 , and 2000.

${ }^{\mathrm{w}}$ Ammonium nitrate was applied during supplemental irrigation at the following rates $\left(\mathrm{kg} \cdot \mathrm{ha}^{-1} \mathrm{~N}\right)$ : 55 in 1995, 100 in 1996, 85 in 1997, 41 in 1998, 64 in 1999, and 52 in 2000.

${ }^{v}$ Mix 1 included crown vetch (Coronilla varia L.), white clover (Trifolium repens L.) and rye cereal (Secale cereale L.).

"Mix 2 consisted of crimson clover (Trifolium incarnatum L.), berseem clover (Trifolium alexandrium L.), and hard fescue (Festuca longifolia Thuill.).

${ }^{\mathrm{t}}$ Mix 3 included red clover (Trifolium pratense L.), white clover, alfalfa (Medicago sativa L.), and annual ryegrass (Lolium multiflorum L.).

${ }^{\mathrm{s}}$ Alternative fertilizers were calcium nitrate $\left(200 \mathrm{~kg} \cdot \mathrm{ha}^{-1}\right)$ in 1995 to 1998 , ammonium sulfate $\left(200 \mathrm{~kg} \cdot \mathrm{ha}^{-1}\right)$ in 1998 to 2000 , and monoammonium phosphate $\left(200 \mathrm{~kg} \cdot \mathrm{ha}^{-1}\right)$ in 1999. 
ability to supply $\mathrm{N}$ to plants. Nematode community structure analysis was used to quantify differences in nematode populations, including communities of herbivores, bacteria feeders, and fungal feeders. Lysimeters were used to measure the amount of $\mathrm{NO}_{3}$ leached as influenced by ground cover and $\mathrm{N}$ fertilizer applications. They were installed in the baseline conventional, the modified conventional using fertigation, and in three of the alternative systems, including two that used a cover crop mix and one of the compost treatments. Yields were recorded for the duration of the experimental period and were used as an indicator of plant performance.

\section{Materials and Methods}

This study was part of the Tart Cherry Groundwater Quality Project (TCGQ), a long-term experiment established in 1995 at the Cherry Bay Orchard adjacent to the Northwest Michigan Horticultural Research Station located near Traverse City. The site experiences cold moist winters and warm humid summers. Average precipitation has been $720 \mathrm{~mm} \cdot \mathrm{yr}^{-1}$ (1995-2000) and potential evapotranspiration typically exceeds precipitation from May through September. The soil is a mixture of Emmet (coarseloamy, mixed, Typic Eutroboralf) and Leelanau (sandy, mixed, frigid, Alfic Haplorthod) loamy sands. The thickness of the Ap horizon is 15 to $22 \mathrm{~cm}$, and $\mathrm{pH}$ ranges from 6.0 to 6.5 . The main goals of the TCGQ are to test alternative integrated orchard pest and production management strategies and achieve nutrient cycling efficiency while reducing chemical input requirements. Experimental plots were established in an 18-year-old, conventionally managed, tart cherry (Prunus cerasus L. 'Montmorency') orchard and arranged in a randomized complete block design with four replications and 13 treatments. Each plot consisted of three rows and five trees per row in a $450-\mathrm{m}^{2}$ area. Rows were spaced $\approx 7 \mathrm{~m}$ apart, with the center $3 \mathrm{~m}$ between rows planted with grass or the corresponding cover crop mix and periodically mowed as an alleyway to support traffic.

Specific treatment information is provided in Table 1. Mulch was applied in one of two ways, either as an external input of supplemental mulch or by a side-delivery mower. In the latter method, a mulch layer was established as the alleyways were mowed, and the biomass [0.5 to $1.0 \mathrm{Mg} \cdot \mathrm{ha}^{-1}$ per year (dry weight basis)] was delivered to the tree rows. Supplemental mulching $\left[10 \mathrm{Mg} \cdot \mathrm{ha}^{-1}\right.$ (dry weight)] was achieved every year by placing rye straw or a balanced hay mix of grasses and legumes. Plots treated with compost received $15 \mathrm{Mg} \cdot \mathrm{ha}^{-1}$ (dry weight) of composted dairy manure the first year and 2 to $3 \mathrm{Mg} \cdot \mathrm{ha}^{-1}$ every year thereafter. Yearly applications were intended to replace the constant mineralization of the large amount applied in the first experimental year. The compost chemical composition in $\mathrm{g} \cdot \mathrm{kg}^{-1}$ (dry weight basis) averaged: 188 of C, 8 of N, 3 of P, 3 of K, 45 of Ca, and 8 of $\mathrm{Mg}$. Extractable $\mathrm{N}$, including $144 \mathrm{mg} \cdot \mathrm{kg}^{-1}$ of $\mathrm{NH}_{4}$ and $545 \mathrm{mg} \cdot \mathrm{kg}^{-1}$ of $\mathrm{NO}_{3}$, were also measured. Mowing under the trees was a common practice in all the alternative treatments. Plots treated with vegetative covers, fertigated $\mathrm{N}$, and the biosystem received some level of supplemental watering through a trickle irrigation system. The primary objectives of using irrigation were to mitigate the competitive effect of living ground covers and to explore the potential of using fertigation as a viable alternative in cherry production systems.

Field MEASUREMENTS. In mid-May 1999 and 2000, soil was sampled in all treatments from within the rows at 0 to $10 \mathrm{~cm}$ depth. The objective of these samplings was to measure selected soil quality parameters, including total organic $\mathrm{C}$ and $\mathrm{N}$ and the active C- and N-pool sizes through their mineralization potentials. Organic residue above the mineral soil was removed in those treatments with a distinct mulch or thatch layer so that the same effective depth of mineral soil was sampled in all treatments. Twelve cores from each plot were composited, placed in plastic bags, and stored at $\approx 4{ }^{\circ} \mathrm{C}$ until processed within $30 \mathrm{~d}$. Additional samples were collected in May 1999 and used to quantify nematode population responses to the variety of treatments tested in this study. In 2001, a more limited sampling was performed to a depth of $10 \mathrm{~cm}$ including the O-horizon (where applicable) to determine how much the soil $\mathrm{C}$ and $\mathrm{N}$ results from the previous years were affected by the removal of this organic material. This sampling included soils from the baseline conventional, supplemental mulch, species mix 2, regular compost, and the biosystem treatments. Pan lysimeters (Parizek and Lane, 1970) placed at 1.4 $m$ depth were used to measure the amount of $\mathrm{NO}_{3}$ leached below the root zone of selected treatments. Water was periodically collected from each lysimeter, its volume recorded, and a subsample of $\approx 1 \mathrm{~L}$ was stored at $4{ }^{\circ} \mathrm{C}$ for chemical analysis. Orchard floor and $\mathrm{N}$ management in each growing season were expected to influence the amount of $\mathrm{NO}_{3}$ leached during the following winter. A leaching year was defined as beginning in May and running through the following April. For instance, the leaching year that started in May 1996 ended in April 1997. Yield was determined by harvesting and weighing all fruit from each tree. In Fall 1995 and 2000, trunk circumference was measured at $0.30 \mathrm{~m}$ above the soil surface and used to calculate the trunk crosssectional area. In Fall 1996 and 2000, populations of vegetative ground cover were counted using the point transect technique (Rickman et al., 1958) then grouped in three major categories: legumes, grasses, and others.

LABORATORY MEASUREMENTS. Soils were sieved through a 6 $\mathrm{mm}$ screen and subsampled for gravimetric moisture determination. Dried soil was analyzed for total organic $\mathrm{C}$ and $\mathrm{N}$ using a NC-S analyzer (NA 1500 Series 2; Carlo Erba Instruments Milan, Italy). The active $\mathrm{N}$ and $\mathrm{C}$ pool sizes were determined using longterm aerobic incubations. Four 20-g dry weight equivalent aliquots of each sample were weighed into 100-mL plastic specimen cups. The soils were brought to $50 \%$ of water holding capacity. The specimen cups were stored in plastic storage containers that had a thin layer of water on the bottom to maintain humidity. These containers were then placed in a controlled temperature room at $25^{\circ} \mathrm{C}$ for $0,30,70$, and $150 \mathrm{~d}$. At the end of each incubation interval, the corresponding samples were removed and frozen temporarily to stop microbial activity. Nitrate- $\mathrm{N}$ and $\mathrm{NH}_{4}-\mathrm{N}$ concentrations were determined using the extraction technique described by Keeney and Nelson (1982) and a Lachat automated colorimetric analyzer (Lachat Instruments Inc. Milwaukee, Wis.). Net $\mathrm{N}$ mineralization potential was calculated using the difference between inorganic $\mathrm{N}$ content at the end of the incubation period and at day 0 . Separate laboratory incubations were used to determine cumulative $\mathrm{C}$ mineralization at 20,30, 50, 70, 100, and $150 \mathrm{~d}$ of incubation. The cumulative mineralization after $150 \mathrm{~d}$ of incubation (150-d C pool) closely represents the active $\mathrm{C}$ pool (Paul et al., 2001). Nematodes were extracted from $100 \mathrm{~cm}^{3}$ soil subsamples using the centrifugation-flotation technique (Jenkins, 1964). They were counted under a stereoscopic microscope and classified according to their feeding behaviors as bacterivores (Rhabditida), fungivores (Aphelenchida and pointed-tail Tylenchida), herbivores (other Tylenchida), omnivores (nonphytopathogenic Dorylaimida), or carnivores (Mononchidas). 
Table 2. Plant frequency distributions in the vegetative cover treatments, expressed as a percentage of the total population in the fall.

\begin{tabular}{|c|c|c|c|c|c|c|}
\hline \multirow[b]{2}{*}{ Treatment } & \multicolumn{3}{|c|}{1996} & \multicolumn{3}{|c|}{2000} \\
\hline & Legumes & Grasses & Others & Legumes & Grasses & Others \\
\hline Species mix 1 & 19 & 59 & 22 & 8 & 63 & 29 \\
\hline Species mix 2 & 15 & 71 & 14 & 3 & 79 & 18 \\
\hline Species mix $2+$ fertigation $\mathrm{N}$ & 14 & 69 & 18 & 2 & 90 & 8 \\
\hline Species mix 3 & 42 & 31 & 27 & 24 & 51 & 25 \\
\hline Natural species mix & 17 & 48 & 35 & 0 & 87 & 13 \\
\hline
\end{tabular}

The objective of this analysis was to look at possible differences in plant parasitic and nonplant parasitic nematode populations. Nitrate-N from the leachate samples was determined using a Lachat analyzer.

Data Analysis. Similar statistical models were applied to the total $\mathrm{C}$ and $\mathrm{N}, \mathrm{NO}_{3}$ leaching, and yield data. Factors used in the model were: year, replication, and management treatment. The $\mathrm{C}$ and $\mathrm{N}$ mineralization analyses used incubation time as an additional factor. Individual observations at each time interval (year and/or incubation time) from all data sets, except total $\mathrm{C}$ and $\mathrm{N}$, were treated as repeated measurements of the corresponding experimental unit. The SAS Mixed procedure (SAS Institute, 2000) was used to fit a mixed linear model with a corresponding covariance structure for each data set. The optimal covariance structure was determined using Schwarz's Bayesian Criterion (Littell et al., 1997). The C and $\mathrm{N}$ mineralization data sets were explained by compound symmetry covariance structures. An unstructured covariance structure, where no mathematical pattern is imposed on the covariance matrix, was the best fit for the leaching data set. Yields were analyzed using the first-order autoregressive covariance structure where correlations increase as the time interval decreases (Littell et at., 1997). After significant effects were identified, differences between least square means were considered significant at 0.05 based on the Tukey adjustment Type I error rate. Nematode populations were analyzed using the SAS Genmod procedure. A model including replication and management treatment factors was used to analyze this data set and the Diff option was used for contrast analysis.

\section{Results and Discussion}

Plant populations were grouped in three major categories: legumes, grasses, and others (Table 2). Of the legumes, red, white, crimson, and berseem clovers, and alfalfa were frequently found. Within the grasses group, hard and tall fescue (Festuca arundinacea Schreb.), orchard grass (Dactylis glomerata L.), bluegrass (Poa pratensis L.), annual and perennial ryegrass (Lolium perenne L.), quack grass (Agropyron repens L.), and crab grass (Digitaria ischaemum Schreb.) were most common. In the 'others' category, the most common species were dandelion (Taraxacum officinale Weber), pigweed (Amaranthus retroflexus L.), lambsquarter (Chenopodium album L.), bladder campion (Silene cucubalus Wibel), horsenettle (Solanum carolinense L.), nightshade (Solanum americanum Mill.), sorrel (Rumex acetosella L.), chickweed (Stellaria media L.), and ragweed (Ambrosia artemisiifolia L.). Grasses were the predominant species in all systems except 'species mix 3' in 1996 (Table 2). However, by 2000, grasses were predominant in 'species mix 3' as well. In addition, there was a general trend for the percentage of grasses to increase between 1996 and 2000.

Alternative orchard floor management strategies were more likely to have a beneficial impact on soil quality by increasing total soil C (Table 3 ). This was achieved by applying mulch or by eliminating spring-applied herbicide in the tree row. Applications of side-delivered or supplemental mulches increased total soil C $>20 \%$ compared to the baseline conventional system. Comparable responses were obtained in soils planted with species mix 2 cover crop and in the biosystem treatment. The highest increase in C was 38\%, found in the natural species mix soil. Total soil $\mathrm{C}$ was negatively influenced by spring application of preemergence herbicide. In contrast, fall herbicide application induced $>28 \%$ gain in soil C compared to the soils receiving herbicide in the spring. The primary difference between spring and fall herbicide application was the duration of the weed-free strip in the tree row during the growing season. Weeds began to regrow in the late spring-early summer where simazine was applied in the fall, whereas the weed-free zone in the spring-applied simazine persisted through late summer. The increase in soil C in the fall-applied herbicide plots may be attributed to weed biomass contributionsin the spring-early summer once the residual effect of simazine was diminished.

Total soil $\mathrm{N}$ was not affected by the amount of $\mathrm{N}$ fertilizer applied or by mode of application. There was no significant difference between treatments receiving $\mathrm{N}$ fertilizer at full rate compared to their fertigated counterpart receiving the reduced rate. However, total soil $\mathrm{N}$ was positively correlated with the presence of natural weeds. The total soil $\mathrm{N}$ where natural weeds were present was $40 \%$ greater than that of the baseline conventional system (Table 3). Fertilizer $\mathrm{N}$ may have been fixed into organic forms by weeds and, thus, became part of the soil organic N pool. Orchard floor management also influenced the $\mathrm{C} / \mathrm{N}$ ratio, with the supplemental mulch plots exhibiting a significant increase in $\mathrm{C} / \mathrm{N}$ ratio. However, the $\mathrm{C} /$ $\mathrm{N}$ ratio decreased in the baseline conventional system and in soils

Table 3. Total organic $\mathrm{C}$ and $\mathrm{N}$ (in $\mathrm{mg} \cdot \mathrm{kg}^{-1}$ ) and $\mathrm{C} / \mathrm{N}$ ratios as affected by orchard floor and $\mathrm{N}$ management.

\begin{tabular}{lrcc}
\hline \hline Treatment & Total C & Total N & C/N ratio \\
\hline Conventional & & & \\
$\quad$ Spr simazine + N & $8,670 \mathrm{~b}^{\mathrm{z}}$ & $713 \mathrm{~b}$ & $12 \mathrm{~b}$ \\
Spr simazine + fertigation N & $8,895 \mathrm{~b}$ & $680 \mathrm{~b}$ & $13 \mathrm{ab}$ \\
$\quad$ Fall simazine + N & $11,405 \mathrm{a}$ & $879 \mathrm{ab}$ & $13 \mathrm{ab}$ \\
Mulch & & & \\
$\quad$ Side deliv & $10,234 \mathrm{a}$ & $848 \mathrm{ab}$ & $12 \mathrm{ab}$ \\
$\quad$ Side deliv+fertigation N & $9,239 \mathrm{ab}$ & $648 \mathrm{~b}$ & $14 \mathrm{a}$ \\
$\quad$ Supplemental & $10,750 \mathrm{a}$ & $740 \mathrm{~b}$ & $15 \mathrm{a}$ \\
Vegetative cover & & & \\
$\quad$ Species mix 1 & $8,741 \mathrm{~b}$ & $719 \mathrm{~b}$ & $12 \mathrm{~b}$ \\
$\quad$ Species mix 2 & $10,230 \mathrm{a}$ & $805 \mathrm{ab}$ & $13 \mathrm{ab}$ \\
$\quad$ Species mix 2 + fertigation N & $9,999 \mathrm{ab}$ & $750 \mathrm{~b}$ & $13 \mathrm{ab}$ \\
$\quad$ Species mix 3 & $9,331 \mathrm{ab}$ & $691 \mathrm{~b}$ & $14 \mathrm{ab}$ \\
$\quad$ Natural species mix & $11,966 \mathrm{a}$ & $1,000 \mathrm{a}$ & $12 \mathrm{~b}$ \\
Compost & & & \\
$\quad$ Regular & $9,602 \mathrm{ab}$ & $725 \mathrm{~b}$ & $13 \mathrm{ab}$ \\
$\quad$ Biosystem & $10,919 \mathrm{a}$ & $860 \mathrm{ab}$ & $13 \mathrm{ab}$
\end{tabular}

$\overline{{ }^{\mathrm{Z}} \text { Least square means within a column followed by a different letter differ }}$ at the 0.05 probability level. 


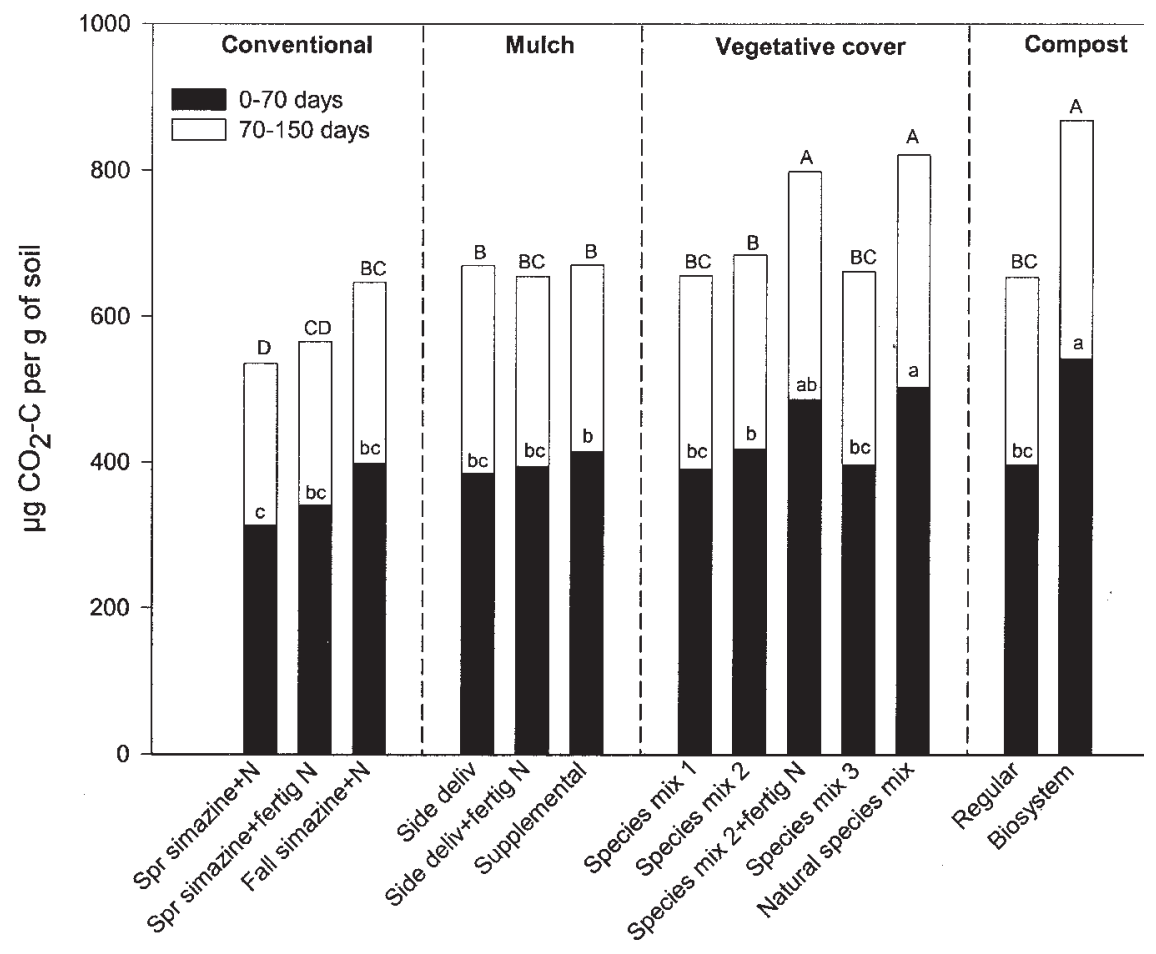

TREATMENTS

Fig. 1. Mineralized soil $\mathrm{C}$ after 70 and $150 \mathrm{~d}$ as affected by $\mathrm{N}$ and orchard floor management in tart cherry. Bars with the same letter are not significantly different (Tukey's adjusted, $P<0.05$ ).

with the species mix 1 or natural species mix ground cover.

The pattern observed in the active $\mathrm{C}$ pool was similar to that found in total $\mathrm{C}$. The size of the active $\mathrm{C}$ pool in the alternative systems soil was enhanced compared to the baseline conventional soil (Fig. 1). Differences were most striking in the biosystem, the natural mix, and the fertigated soil planted with species mix 2 . The ments when contrasted with the baseline conventional. The amount of $\mathrm{N}$ mineralized from cover cropped soils was lower than expected. The predominance of grasses and the reduction of legume populations from 1996 to 2000 (Table 2) likely contributed to this result where soils were planted with a cover crop mix. An important increase of $40 \%$ in the $150-\mathrm{d} \mathrm{N}$ pool was found in the fall-treated conventional system, following the pattern encountered when looking at total C and active $\mathrm{C}$ in this treatment. Collectively, these data support the hypothesis that living ground cover, including natural weed species, plays an active role in maintaining or increasing soil organic matter (Sanchez et al., 2001).

The single spring application of fertilizer $\mathrm{N}$ in conjunction with spring applied simazine in the baseline conventional system showed the lowest amount of mineralized $\mathrm{N}$ compared to the other orchard floor management systems (Fig. 2). In contrast, the increase in active $\mathrm{N}$ in soil treated with spring simazine plus fertigated $\mathrm{N}$ was surprising. As in the baseline conventional system, there was only a brief time period during which vegetative growth was not suppressed by simazine, hence no significant amount of weed biomass was available to enter the soil. We suggest that the difference may be attributed to $\mathrm{N}$ fixation in the soil organic matter, including microbial biomass, facilitated by timely releases of lower amounts of $\mathrm{N}$ from the fertigation system. In contrast, the single spring application of large amounts of fertil-

Fig. 2. Net mineralized $\mathrm{N}$ after 70 and $150 \mathrm{~d}$ of laboratory incubation as affected by $\mathrm{N}$ and orchard floor management in tart cherry. Lower-case and upper-case letters indicate significant differences in mineralized $\mathrm{N}$ at day 70 and 150 , respectively (Tukey's adjusted, $P<0.05$ ). $150-\mathrm{d} C$ pool in these treatments was $45 \%$ to $60 \%$ greater than that of the baseline conventional. The size of the active $\mathrm{C}$ pool also increased in the fall-treated conventional system. As with total $\mathrm{C}$, this increase appears to be related to the presence of actively growing weeds (i.e., weed biomass contributions and the associated increase in soil microbial activity) in the spring-early summer. Trends in the 70-d C pool follow the $150 \mathrm{~d}$, but the differences among treatments are not as great as in the $150 \mathrm{~d}$. The quality of the organic materials entering the soil as mulch, cover crop residues, and compost may have influenced those differences. The effect of residue quality, as defined by the chemical composition of the organic materials, on decomposition has been extensively documented (Heal et al., 1997; Sanchezet al., 2001; Swift et al., 1979; Tian et al., 1997).

The size of the active $\mathrm{N}$ pool, indicated by net $\mathrm{N}$ mineralization at $150 \mathrm{~d}$, was also affected by orchard floor management (Fig. 2). Increases in the 150-d N pool ranged from $25 \%$ in the treatments using mulch or a vegetative mix to $60 \%$ in both compost treat-

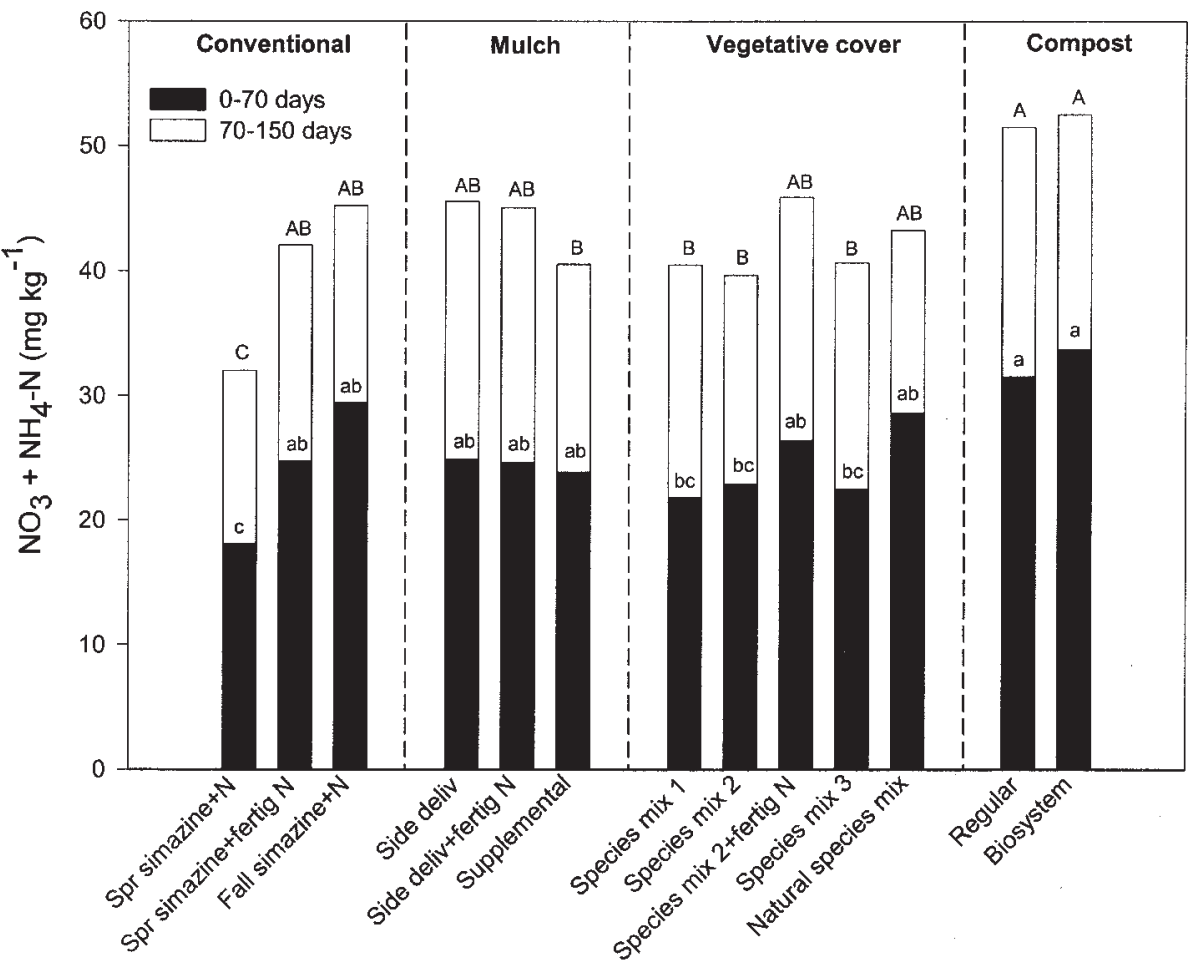

TREATMENTS 
Table 4. Nematode community structure expressed in populations of plant parasitic (pp), bacteria feeders, and fungal feeders, nonplant parasitic (npp), total nematodes, and npp/pp ratios. Soil samples were taken in May 1999 at the 0 to $15 \mathrm{~cm}$ soil profile.

\begin{tabular}{|c|c|c|c|c|c|c|}
\hline \multirow[b]{2}{*}{ Treatment } & \multicolumn{5}{|c|}{ Nematodes $/ 100 \mathrm{~cm}^{3}$ soil } & \multirow[b]{2}{*}{$\mathrm{npp} / \mathrm{pp}$} \\
\hline & $\begin{array}{c}\text { Plant } \\
\text { parasitic }\end{array}$ & $\begin{array}{c}\text { Bacterial } \\
\text { feeders }\end{array}$ & $\begin{array}{l}\text { Fungal } \\
\text { feeders }\end{array}$ & $\begin{array}{l}\text { Nonplant } \\
\text { parasitic }\end{array}$ & Total & \\
\hline \multicolumn{7}{|l|}{ Conventional } \\
\hline Spring simazine $+\mathrm{N}$ & $55 \mathrm{ab}^{\mathrm{z}}$ & $101 \mathrm{bc}$ & $24 b$ & $203 \mathrm{bc}$ & $258 \mathrm{~b}$ & $3 \mathrm{de}$ \\
\hline Spring simazine + fertigation $\mathrm{N}$ & $50 \mathrm{ab}$ & $122 \mathrm{bc}$ & $38 \mathrm{~b}$ & $206 \mathrm{bc}$ & $256 \mathrm{~b}$ & $5 \mathrm{~cd}$ \\
\hline Fall simazine $+\mathrm{N}$ & $97 \mathrm{a}$ & $90 \mathrm{bc}$ & $26 b$ & $165 \mathrm{c}$ & $261 \mathrm{~b}$ & $2 \mathrm{e}$ \\
\hline \multicolumn{7}{|l|}{ Mulch } \\
\hline Side delivery & $69 \mathrm{ab}$ & $104 \mathrm{bc}$ & $48 \mathrm{~b}$ & $254 \mathrm{bc}$ & $324 b$ & $6 \mathrm{bc}$ \\
\hline Side delivery + fertigation $\mathrm{N}$ & $61 \mathrm{ab}$ & $103 \mathrm{bc}$ & $52 \mathrm{~b}$ & $267 \mathrm{bc}$ & $329 b$ & $5 \mathrm{~cd}$ \\
\hline Supplemental & $50 \mathrm{ab}$ & $144 \mathrm{~b}$ & $60 \mathrm{ab}$ & $294 \mathrm{bc}$ & $343 b$ & $7 \mathrm{bc}$ \\
\hline \multicolumn{7}{|l|}{ Vegetative cover } \\
\hline Species mix 1 & $87 \mathrm{a}$ & $279 a$ & $65 \mathrm{ab}$ & $519 a$ & $609 a$ & $6 \mathrm{bc}$ \\
\hline Species mix 2 & $55 \mathrm{ab}$ & $167 \mathrm{ab}$ & $53 \mathrm{~b}$ & $301 \mathrm{~b}$ & $357 \mathrm{ab}$ & $8 \mathrm{~b}$ \\
\hline Species mix $2+$ fertigation $\mathrm{N}$ & $79 a$ & $70 c$ & $38 \mathrm{~b}$ & $201 \mathrm{bc}$ & $280 \mathrm{~b}$ & 3 de \\
\hline Species mix 3 & $62 \mathrm{ab}$ & $266 \mathrm{a}$ & $115 \mathrm{a}$ & $459 \mathrm{a}$ & $524 \mathrm{a}$ & $6 \mathrm{bc}$ \\
\hline Natural species mix & $52 \mathrm{ab}$ & $99 \mathrm{bc}$ & $26 \mathrm{~b}$ & $201 \mathrm{bc}$ & $254 \mathrm{~b}$ & $4 \mathrm{de}$ \\
\hline \multicolumn{7}{|l|}{ Compost } \\
\hline Regular & $52 \mathrm{ab}$ & $149 \mathrm{bc}$ & $50 \mathrm{~b}$ & $270 \mathrm{bc}$ & $321 \mathrm{~b}$ & $8 \mathrm{~b}$ \\
\hline Biosystem & $32 \mathrm{~b}$ & $216 a b$ & $60 \mathrm{ab}$ & $364 \mathrm{ab}$ & $398 \mathrm{ab}$ & $13 \mathrm{a}$ \\
\hline
\end{tabular}

${ }^{\mathrm{z}}$ Least square means within a column followed by a different letter differ at the 0.05 probability level.

izer $\mathrm{N}$ in the baseline conventional system may have resulted in considerable losses of $\mathrm{N}$ to the environment.

The decision to remove organic residues above mineral soil in the 1999 and 2000 soil samples may have resulted in a substantial underestimation of the potentially mineralizable $\mathrm{C}$ and $\mathrm{N}$ in those treatments with a buildup of mulch or thatch. We tested this hypothesis by obtaining a limited number of samples with their organic horizons intact during spring 2001. Carbon and N mineralization potentials were two times higher for all treatments except the supplemental mulch treatment, which was three times higher when compared to the previous years (data not shown). This suggests that the sampling technique used during 1999 and 2000 may have underestimated $\mathrm{C}$ and $\mathrm{N}$ mineralization potentials in all treatments, especially the supplemental mulch treatment.

One of the benefits of increasing the active $\mathrm{C}$ and $\mathrm{N}$ pools is enhancing the ability of soil to provide $\mathrm{N}$ to a growing plant (Sanchez et al., 2001). This is accomplished, in part, by stimulating interactions among soil biota which can play a significant role in nutrient transformations and plant nutrient availability (Coleman et al., 1984). The presence of high quality decomposing materials acts as a fuel for a sequence of events that is unlikely to take place in the absence of these compounds. Microbial activity is stimulated because soil microorganisms are typically $\mathrm{C}$-limited (Paul and Clark, 1996). Consequently, net $\mathrm{N}$ mineralization is expected to increase with microbial activity as the $\mathrm{C} / \mathrm{N}$ ratio in the soils becomes more favorable.

Based on earlier work (Sanchez et al., 2001), we assumed that increases in mineralized $\mathrm{N}$ would generally be related to greater bacterial and fungal activity. In the present study, the size and structure of nematode communities were used as indicators of the soil microbial activity and possible plant health impacts. Because of the diversity of their feeding habits, nematode community structure should be impacted by orchard management practices. For instance, there was over a 2-fold increase in the number of total nematodes with the use of cover crop species mixes 1 and 3 compared to the conventional systems (Table 4). This remarkable gain in nematode population was led by an enhanced population of bacterial and fungal feeders. From an ecological point of view, it is reasonable to expect that increases in the population of microbial feeding nematodes would be associated with an increase in microbial production. Clarholm (1985) and Robinson et al. (1989) reported that some mineralized $\mathrm{N}$ originates from the increased microbial turnover resulting from predation of an enhanced microbial biomass. Indeed, Maxwell and Coleman (1995) studied a hardwood forest ecosystem where microbivorous nematodes were sufficiently numerous to keep bacterial and

Table 5. Nitrate-N leached beneath the root zone in selected orchard floor and $\mathrm{N}$ management.

\begin{tabular}{|c|c|c|c|c|c|}
\hline \multirow[b]{2}{*}{ Treatment } & \multicolumn{5}{|c|}{ Nitrate-N $\left(\mathrm{kg} \cdot \mathrm{ha}^{-1}\right)$} \\
\hline & 1996 & 1997 & 1998 & 1999 & Overall \\
\hline \multicolumn{6}{|l|}{ Conventional } \\
\hline Spring simazine $+\mathrm{N}$ & $88.7 \mathrm{a}^{2}$ & $20.7 \mathrm{a}$ & $49.7 \mathrm{a}$ & $26.9 \mathrm{a}$ & $46.5 \mathrm{a}$ \\
\hline Spring simazine + fertigation $N$ & $7.1 \mathrm{~b}$ & $3.3 \mathrm{~b}$ & $1.3 \mathrm{~b}$ & $1.0 \mathrm{~b}$ & $3.2 \mathrm{~b}$ \\
\hline \multicolumn{6}{|l|}{ Vegetative cover } \\
\hline Species mix 2 & $19.2 \mathrm{~b}$ & $2.0 \mathrm{~b}$ & $1.0 \mathrm{~b}$ & $1.8 \mathrm{~b}$ & $6.0 \mathrm{~b}$ \\
\hline Species mix $2+$ fertigation $\mathrm{N}$ & $12.9 \mathrm{~b}$ & $2.0 \mathrm{~b}$ & $1.0 \mathrm{~b}$ & $1.3 \mathrm{~b}$ & $4.2 \mathrm{~b}$ \\
\hline \multicolumn{6}{|l|}{ Compost } \\
\hline Regular & $26.2 \mathrm{~b}$ & $3.3 \mathrm{~b}$ & $0.8 \mathrm{~b}$ & $0.2 \mathrm{~b}$ & $7.7 \mathrm{~b}$ \\
\hline
\end{tabular}


Table 6. Tart cherry yields as affected by nitrogen and orchard floor managements.

\begin{tabular}{|c|c|c|c|c|c|c|c|}
\hline \multirow[b]{2}{*}{ Treatment } & \multicolumn{7}{|c|}{ Cherry yield $\left(\mathrm{t} \cdot \mathrm{ha}^{-1}\right)$} \\
\hline & 1995 & 1996 & 1997 & 1998 & 1999 & 2000 & Overall \\
\hline \multicolumn{8}{|l|}{ Conventional } \\
\hline Spring simazine $+\mathrm{N}$ & $14.8 \mathrm{~cd}^{\mathrm{z}}$ & $22.0 \mathrm{~b}$ & $11.0 \mathrm{bc}$ & $20.9 \mathrm{~b}$ & $16.4 \mathrm{~b}$ & $10.2 \mathrm{ab}$ & $15.9 \mathrm{~cd}$ \\
\hline Spring simazine+fertig $\mathrm{N}$ & $16.9 \mathrm{ab}$ & $23.3 \mathrm{a}$ & $13.0 \mathrm{ab}$ & $22.2 \mathrm{ab}$ & $16.2 \mathrm{~b}$ & $9.1 \mathrm{ab}$ & $16.8 \mathrm{bc}$ \\
\hline Fall simazine $+\mathrm{N}$ & $18.4 \mathrm{a}$ & $21.5 \mathrm{~b}$ & $15.4 \mathrm{a}$ & $18.4 \mathrm{bc}$ & $15.1 \mathrm{bc}$ & $10.2 \mathrm{ab}$ & $16.5 \mathrm{bc}$ \\
\hline \multicolumn{8}{|l|}{ Mulch } \\
\hline Side deliv & $16.5 \mathrm{ab}$ & $21.6 \mathrm{~b}$ & $12.4 \mathrm{ab}$ & $22.0 \mathrm{ab}$ & $16.7 \mathrm{ab}$ & $9.0 \mathrm{ab}$ & $16.4 \mathrm{bc}$ \\
\hline Side deliv+fertig $\mathrm{N}$ & $14.4 \mathrm{~cd}$ & $24.4 \mathrm{a}$ & $12.1 \mathrm{bc}$ & $23.7 \mathrm{a}$ & $18.9 \mathrm{a}$ & $11.3 \mathrm{a}$ & $17.5 \mathrm{ab}$ \\
\hline Supplemental & $17.4 \mathrm{ab}$ & $25.6 \mathrm{a}$ & $12.7 \mathrm{ab}$ & $24.8 \mathrm{a}$ & $19.8 \mathrm{a}$ & $11.0 \mathrm{a}$ & $18.5 \mathrm{a}$ \\
\hline \multicolumn{8}{|l|}{ Vegetative cover } \\
\hline Species mix 1 & $14.1 \mathrm{~cd}$ & $20.5 \mathrm{~b}$ & $12.3 \mathrm{ab}$ & $20.4 \mathrm{bc}$ & $13.7 \mathrm{~cd}$ & $9.5 \mathrm{ab}$ & $15.1 \mathrm{~cd}$ \\
\hline Species mix 2 & $13.7 \mathrm{~d}$ & $20.5 \mathrm{~b}$ & $12.0 \mathrm{bc}$ & $17.9 \mathrm{c}$ & $13.1 \mathrm{~cd}$ & $9.5 \mathrm{ab}$ & $14.5 \mathrm{de}$ \\
\hline Species mix $2+$ fertig $N$ & $16.6 \mathrm{ab}$ & $22.8 \mathrm{ab}$ & $12.6 \mathrm{ab}$ & $20.2 \mathrm{bc}$ & $14.5 \mathrm{bc}$ & $7.7 \mathrm{~b}$ & $15.8 \mathrm{~cd}$ \\
\hline Species mix 3 & $13.6 \mathrm{~d}$ & $21.0 \mathrm{~b}$ & $9.3 \mathrm{c}$ & $20.4 \mathrm{bc}$ & $14.2 \mathrm{bc}$ & $8.3 \mathrm{ab}$ & $14.5 \mathrm{de}$ \\
\hline Natural species mix & $14.9 \mathrm{~cd}$ & $20.3 \mathrm{~b}$ & $11.1 \mathrm{bc}$ & $19.1 \mathrm{bc}$ & $14.4 \mathrm{bc}$ & $8.5 \mathrm{ab}$ & $14.7 \mathrm{de}$ \\
\hline \multicolumn{8}{|l|}{ Compost } \\
\hline Regular & $15.9 \mathrm{bc}$ & $23.1 \mathrm{ab}$ & $12.9 \mathrm{ab}$ & $21.2 \mathrm{~b}$ & $13.2 \mathrm{~cd}$ & $8.8 \mathrm{ab}$ & $15.9 \mathrm{~cd}$ \\
\hline Biosystem & $14.2 \mathrm{~cd}$ & $20.2 \mathrm{~b}$ & $10.2 \mathrm{bc}$ & $17.2 \mathrm{c}$ & $12.6 \mathrm{~d}$ & $9.5 \mathrm{ab}$ & $14.0 \mathrm{e}$ \\
\hline
\end{tabular}

${ }^{\mathrm{z}}$ Least square means within a column followed by a different letter differ at the 0.05 probability level.

fungal populations more or less in check. In such cases, microbial production may be best reflected by studying populations at a higher trophic level.

Enhancing soil organic matter and stimulating microbial activity while increasing the proportion of nonplant parasitic nematodes effectively decreased the proportion of plant parasitic species. The use of composted manure plus alternative fertilizers in the biosystem treatment was associated with significantly reduced populations of plant parasitic nematodes compared to the fall treated conventional or the cover crops mixes 1 and 2 (Table 4 ). In contrast, mulches or cover crop mixes did not decrease the number of plant parasitic nematodes compared to any of the conventional systems. The potential benefit for controlling plant parasitic populations appears to be related to the increasing number of nonplant parasitic nematodes. With the sole exception found in the fertigated species mix 2 , the number of beneficial nematodes relative to herbivores tended to increase with the use of alternative orchard floor and $\mathrm{N}$ management. We speculate that this change in nematode community structure would increase competition for space and resources in favor of the beneficial communities and growing plants.

When simazine was used, $\mathrm{NO}_{3}$ concentration beneath the root zone was dependent on the rate and method of $\mathrm{N}$ fertilizer applications. Using $\mathrm{N}$ fertilizer at full rate induced an overall 15fold increase in the amount of $\mathrm{NO}_{3}$ leached when compared to the fertigated system using the reduced rate (Table 5). Comparable reductions in leaching losses were obtained in the cover crop mix or compost treatments. The dramatic reduction associated with the presence of a vegetative cover was present across all $\mathrm{N}$ fertilizer rates. There were no significant differences in the amount of $\mathrm{NO}_{3}$ leached from the cover cropped soils receiving either full or the reduced $\mathrm{N}$ rate or the compost treatment receiving no additional fertilizer. The amount of $\mathrm{NO}_{3}$ leaching losses tended to vary by season, depending on the agronomic and climatic conditions. Regardless of seasonal differences, losses in the conventional spring system managed with preemergent herbicide and using $\mathrm{N}$ at full rate were consistently higher than the other treatments throughout the experimental period (Table 5).
One of the key arbiters for tart cherry growers is the impact of alternative systems on yield. An overall contrast of yield data for this study indicated that alternative orchard floor and $\mathrm{N}$ management systems enhanced tart cherry yields in some cases, and decreased them in other treatments when compared to the baseline conventional system (Table 6). The use of supplemental mulch or side delivered mulch plus fertigated $\mathrm{N}$ significantly increased yields by $16 \%$ and $10 \%$, respectively, compared to the baseline conventional system (Table 6). This enhanced performance was likely related to greater water availability in the mulch systems. Other studies have reported the benefits of mulching in conserving soil moisture (Fleming and Alderfer, 1952; Longstroth and Perry, 1996). Conversely, the competitive effect of vegetative cover was evident when comparing yields of the mulched plots to those using a living ground cover mix. Significant yield reductions in the vegetative-covered treatments appear to be related to a less than optimal uptake of water and N. Using trickle irrigation possibly reduced, but did not eliminate, the detrimental effect of living ground cover on the amount of water available for the cherry trees and crop. Agronomic handling of cover crop mixes may have a tremendous influence in determining the levels of competition. Cover crop mixes were planted in the first year and generally left unmanaged for the duration of the experiment. Early in the experiment, when grasses were less predominant (Table 2), yields were not reduced as a result of the cover crop mixes. Yield reduction in the following years appears to be related to increased competition from the more $\mathrm{N}$ demanding grasses. Detrimental effects to fruit trees associated with grass competition have been widely reported in a number of studies (Anderson et al., 1992; Lyon et al., 1925; Robinson and O'Kennedy, 1978). It is noteworthy that increased amounts of $\mathrm{N}$ fertilizer did not increase yields in our study. Yields in the conventional fertigated plots receiving the reduced rate were higher than the baseline conventional in 2 out of 6 years with no significant differences for the other 4 years. Yield efficiency ratings, measured by the weight of fruit per square centimeter of trunk cross sectional area, were not significantly different among treatments (data not shown). This indicates that yield differences among some of the treatments were related primarily to tree size. 


\section{Conclusions}

Alternative orchard floor and $\mathrm{N}$ management strategies have the potential to enhance soil and water quality while maintaining or even increasing tart cherry yields. Soil C and N, including their mineralizable forms, were increased with the use of mulches, cover crop mixes, and composted manure applications when compared to a conventional system that uses preemergence herbicide and $\mathrm{N}$ fertilizer at full standard rate. In addition to other possible benefits associated with increased soil organic matter, the ability of these soils to provide $\mathrm{N}$ to a growing plant is increased. This represents a very important step toward achieving sustainable $\mathrm{N}$ supplies for fruit production. Enhancing microbial activity by increasing the active $\mathrm{C}$ and $\mathrm{N}$ pools is likely to increase the proportion of beneficial nematodes relative to herbivores, creating a more competitive environment that can help keep disease organisms or parasites from becoming problems.

This study was designed to test plant and soil responses to specific treatments on mature cherry trees. It is clear that most of the alternatives tested here were able to improve soil quality while maintaining or increasing yields compared to the baseline conventional system. Further testing will be required, however, to determine the cost effectiveness of these treatments, and to confirm that they are useful in orchards with younger trees. It is almost certain that the optimum tart cherry production system would include a combination of the strategies tested in this study. Further research will be needed to determine the optimal combination of mulch, cover crops, compost, and fertilizer $\mathrm{N}$ applications to produce a more ecologically and economically sustainable tart cherry production system.

\section{Literature Cited}

Anderson, J.L., G.E. Bingham, and R.W. Hill. 1992. Effects of permanent cover crop competition on sour cherry tree evapotranspiration, growth, and productivity. Acta Hort. 313:135-142.

Castellanos, J.Z. and P.F. Pratt. 1981. Mineralization of manure nitrogenCorrelation with laboratory indexes. Soil Sci. Soc. Amer. J. 45:354-357.

Clarholm, M. 1985. Interactions of bacteria, protozoa and plants leading to mineralization of soil nitrogen. Soil Biol. Biochem. 17:181-187.

Coleman D.C., R.V. Anderson, C.V. Cole, J.F. McClellan, L.E. Woods, J.A. Trofymow, and E.T. Elliot. 1984. Role of protozoa and nematodes in nutrient cycling, p. 17-28. In: R.L. Todd et al. (eds.). Microbial-plant interactions. ASA Spec. Publ. 47.

Fleming, H.K. and R.B. Alderfer. 1952. Soil management in a young 'Montmorency' sour cherry orchard. Pa. Agr. Expt. Sta. Bul. 557.

Goode, J.E. and K.J. Hyrycz. 1976. The effect of nitrogen on young, newly planted apple rootstocks in the presence and absence of grass competition. J. Hort. Sci. 51:321-327.

Hanson, E.J. and E.L. Proebsting. 1996. Cherry nutrient requirements and water relations, p. 243-257. In: A.D. Webster and N.E. Looney (eds.). Cherries: Crop physiology, production and uses. CAB Intl., Wallingford, U.K.

Heal, O.W., J.M. Anderson, and M.J. Swift. 1997. Plant litter quality and decomposition: An historical overview, p. 3-30. In: G. Cadisch and K.E. Giller (eds.). Driven by nature: Plant litter decomposition. CAB Intl., Wallingford, U.K.

Hesterman, O.B., C.C. Sheaffer, D.K. Barnes, W.E. Lueschen, and J.H. Ford. 1986. Alfalfa dry matter and nitrogen production, and nitrogen response in legume-corn rotations. Agron. J. 78:19-23.

Jenkins, W.R. 1964. A rapid centrifuge-flotation technique for separating nematodes from soil. Plant Dis. Rptr. 48:692.
Keeney, D.R., and D.W. Nelson. 1982. Nitrogen-Inorganic forms, p. 643-698. In: A.L. Page, R.H. Miller, and D.R. Keeney (eds.). Methods of soil analysis. Part 2. $2^{\text {nd }}$ ed. ASA Agron. Monogr. 9.

Keeney, D.R. 1989. Sources of nitrate to groundwater, p. 23-34. In: R.F. Follet (ed.). Nitrogen management and groundwater protection. Elsevier, New York.

Kotschi,J., A. Waters-Bayer, R. Adelhelm, and U.Hoesle. 1990.Ecofarming in agricultural development. Verlag Josef Margraf, Weikersheim.

Littell, R.C., G.A. Milliken, W.W. Stroup, and R.D. Wolfinger. 1997. SAS system for mixed models. SAS Inst. Inc., Cary, N.C.

Longstroth M. and R.L. Perry. 1996. Selecting the orchard site, orchard planning and establishment, p. 203-221. In: A.D. Webster and N.E. Looney (eds.). Cherries: Crop physiology, production and uses. CAB Intl., Wallingford, U.K.

Lyon, T.L., A.J. Heinicke, and B.D. Wilson. 1925. The relation of soil moisture and nitrates to the effects of sod on plum and cherry trees. Cornell Univ. Agr. Expt. Sta. Mem. 91.

Maxwell, R.A. and D.C. Coleman. 1995. Seasonal dynamics of nematode and microbial biomass in soils of riparian-zone forests of the southern Appalachians. Soil Biol. Biochem. 27:79-84.

McKenney, D.J., S.W. Wang, C.F. Drury, and W.I. Findlay. 1993. Denitrification and mineralization in soil amended with legume, grass, and corn residues. Soil Sci. Soc. Amer. J. 57:1013-1020.

Merwin, I.A. 1998. Integrated systems for orchard weed and soil management. Mich. State Hort. Soc., Morrice, Mich. p. 159-168.

Parizek R.R. and B.E. Lane. 1970. Soil-water sampling using pan and deep pressure-vacuum lysimeter. J. Hydrol. 11:1-21.

Parker, M.L. and J. Hull. 1993. Orchard floor management affects cherry tree growth and moisture utilization. Acta Hort. 343:201-213.

Paul, E.A. and F.E. Clark. 1996. Soil microbiology and biochemistry. Academic Press, San Diego, Calif.

Paul, E.A., S.J. Morris, and S. Bohm. 2001. The determination of soil C pool sizes and turnover rates: Biophysical fractionation and tracers, $\mathrm{p}$. 193-206. In: R. Lal, J. Kimble, and R. Follett (eds.). Assessment methods for soil carbon pools. CRC Press, Boca Raton, Fla.

Rickman, R.W., S.E. Waldman, J.E. Morrison, and D.K. McCool. 1958. Point transect estimates of residue cover or crop canopy in rows. Amer. Soc. Agr. Eng., St. Joseph, Mich.

Robinson, D., B. Griffiths, K Ritz, and R. Wheatley. 1989. Root-induced nitrogen mineralization: A theoretical analysis. Plant and Soil. 117:185193.

Robinson, D.W. and N.D. O'Kennedy. 1978. The effect of overall herbicide systems of soil management on the growth and yield of apple trees 'Golden Delicious'. Scientia Hort. 9:127-136.

Sanchez, J.E., T.C. Willson, K. Kizilkaya, E. Parker, and R.R. Harwood. 2001. Enhancing the mineralizable nitrogen pool through substrate diversity in long term cropping systems. Soil Sci. Soc. Amer. J. 65:14421447.

SAS Institute. 1999. The SAS system for Windows. Release 8.0. SAS Inst., Cary, NC.

Shribbs, J.M. and W.A. Skroch. 1986. Influence of 12 ground cover systems on young 'Smoothee Golden Delicious' apple trees: I. Growth. J. Amer. Soc. Hort. Sci. 111:525-528.

Smith, C.B., H.K. Fleming, and L.T. Kardos. 1961. Leaf composition and performance of sour cherry trees as influenced by fertilizer and soil management. Pa. Agr. Expt. Sta. Bul. 683.

Swift, M.J., O.W. Heal, and J.M. Anderson. 1979. Decomposition in terrestrial ecosystems. Studies in ecology 5. Blackwell, Oxford.

Tian, G., L. Brussaard, B.T. Kang, and M.J. Swift. 1997. Soil faunamediated decomposition of plant residues under constrained environmental and residue quality conditions, p. 125-134. In: G. Cadisch and K.E. Giller (eds.). Driven by nature: Plant litter decomposition. CAB Intl., Wallingford, U.K. 